\title{
POLITICAL TERROR OF THE 1920s AND 1930s AGAINST THE SCIENTIFIC INTELLIGENTSIA OF UKRAINE IN THE PHILOSOPHICAL INTERPRETATION OF THE POLICY OF TOTALITARIANISM
}

\author{
N. M. Lytvyn \\ Kyiv National University of Trade and Economics \\ n.lytvyn@knute.edu.ua \\ https://orcid.org/0000-0003-0555-0485 \\ V. Yo. Razitskyi \\ Kyiv National University of Trade and Economics \\ v.razitskyy@knute.edu.ua \\ https://orcid.org/0000-0002-1048-3419
}

Key words: totalitarianism, political repressions, intelligentsia, ideology, terror.
The article presents an analysis of the policy of totalitarianism by the Communist Party and its leaders, namely the methods of struggle against the scientific intelligentsia. Much attention is paid to the ideological component of the struggle against the scientific intelligentsia, methods of ideological pressure against individual freedom and propaganda of the ideological justification of political repression are shown in terms of ideology and politics of that time, examples of philosophical interpretation of terror, which reached its apogee in the 1930s in Ukraine, are provided.
Problem statement. The problem of totalitarianism is deep, existential, it concerns the nature of human existence. After all, human inner desire for a comprehensive order around oneself, systematization of all forms and events, attaching meaning to the world, anxiety about future major changes, human conservatism, rejection of the responsibility for decisions, "escape from freedom" (E. Fromm), etc. - all this becomes an important prerequisite for the formation of a specific system of state and political power that regulates and controls all public and private spheres of human life. With the victory of Soviet power and the establishment of the Communist Party's monopoly on public life, the Ukrainian intelligentsia lost the right to independent political thought, freedom of speech, and freedom of assembly. This led to a sharp separation of views in its environment. Part of the Ukrainian elite believed the Bolsheviks' promises to recognize the sovereign USSR. It accepted this as a reality, not as a strategic political maneuver, and chose the tactic of adapting to Soviet power. The rest of the intelligentsia expressed their open disapproval of Soviet power and Bolshevik policy. It was this intelligentsia that suffered the most. In essence, the intelligentsia sought universal principles. As a result, confrontation between the Party and the intelligentsia, both in ideology and politics, was inevitable. The Bolsheviks chose their path to resolve this contradiction. It was a way of complete subordination and subjugation of cultural life to the official ideology. The Ukrainian intelligentsia in the 1920s and 1930s came under pressure from a brutal totalitarian system. A whole arsenal of measures was used against it: from ideological to repressive tools. Repressions against the intelligentsia required justification of their expediency in the eyes of the people. In such circumstances, this led to the de facto legitimization of the policy of terror.

Analysis of basic research and publications. Political repression in the USSR is widely reflected in modern historiography. However, the problem of ideological justification of the policy of terror by Party-Soviet leaders from the point of view of the philosophy of totalitarianism remains insufficiently studied by researchers. This problem is relevant because political terror is considered not from the point of view of the practice of repression, but from the point of view of their ideological expediency.

The concept of totalitarianism as a political system is thoroughly considered in the works by $\mathrm{H}$. Arendt, K. Popper, E. Fromm, F. Hayek, K. Friedrich, Z. Brzezinski, R. Anderson, and others. The famous philosopher and sociologist K. Popper in his work "Open Society and Its Enemies" emphasizes that 
Plato laid the first ideological origins of the totalitarian "closed" society with all its terrible features in the modern liberal sense: the oppression of humanistic ideals, individualism, egalitarianism, etc. ${ }^{1}$

As for the analysis of recent research on this topic, most of them is published after 1991. The works of Russian researchers, as Korzhikhina' T.P., Kumanev V.0. ${ }^{3}$, Sharapov Yu.P. ${ }^{4}$, Venzher V.G. ${ }^{5}$, and others, describe the trials, the activities of the NKVD. Also, these historical events and the scientific perspective on them are reflected in the works by Ukrainian researchers: Danylenko V.M. ${ }^{6}$, Kasyanov G.V., Kulchytsky S.V., Chentsov V.V. ${ }^{7}$, Ocheretyanko V.I. ${ }^{8}$, Bilokin S. ${ }^{9}$, Podkur R.Yu. ${ }^{10}$, Bezotosny M.T., Shapoval Yu.I. ${ }^{11}$ and others. The generalizing work by many Ukrainian researchers on the policy of terror is "Political terror and terrorism in Ukraine"12. In all these works, there is a certain reflection of the philosophical and ideological justification of the policy of terror. However, such aspects as the attitude of the Party-Soviet leaders to the intelligentsia, their interpretation of the policy of terror, and how this interpretation was explained to the people, require more in-depth scientific research.

The source base of the study is archival documents and materials. The author has studied and analyzed a significant array of documents and materials deposited in the funds of the Central State

\footnotetext{
${ }^{1}$ Popper K. The Open Society and Its Enemies. Vol. 1: The Spell of Plato; translated from English, ed. by V.N. Sadovsky. - M.: Feniks, 1992. - P. 123-124 [In Russian]

${ }^{2}$ Korzhikhina T. Please be trustworthy / T. Korzhikhina T. - M., 1997.-372 p. [In Russian].; Kumanev V. 30s in the destinies of the domestic intelligentsia / Kumanev V. - M.,1991.- 296 p. [In Russian]

${ }^{3}$ Kumanev V. 30 s in the destinies of the domestic intelligentsia / Kumanev V. - M.,1991. - 296 p. [In Russian].

${ }^{4}$ Sharapov Yu. From the history of the ideological struggle during the transition to NEP: petty-bourgeois revolutionism the danger "from the left" / Yu. Sharapov. - M., 1990. -190 p. [In Russian].

${ }^{5}$ Venzher, V. As it was, as it could be, as it became, as it should be / V. Venzher. - M., 1990.-110 p. [In Russian].

${ }^{6}$ Danylenko, V. Stalinism in Ukraine: 20-30s / V. Danylenko, G. Kasyanov, S. Kulchytsky. - K., 1991. - 344 p. [In Ukrainian]

${ }^{7}$ Chentsov V. Political repression in Soviet Ukraine in the 1920s / V. Chentsov. - Ternopil, 2000.-482 p. [In Ukrainian].

${ }^{8}$ Ocheretyanko V. Tempered thought / V. Ocheretyanko. - K., 2000. -150 p. [In Ukrainian].

${ }^{9}$ Bilokin S. The mechanism of Bolshevik violence / S. Bilokin. K., 2000. - 128 p. [In Ukrainian].

${ }^{10}$ Podkur R. According to Soviet special services / R. Podkur. K., 2000. - 230 p. [In Ukrainian].

${ }^{11}$ Shapoval Y. In those tragic years: Stalinism in Ukraine / Y. Shapoval. - K., 1990. - 143 p. [In Ukrainian]

${ }^{12}$ Kulchytsky S. Political terror and terrorism in Ukraine in the 19th-20th centuries: historical essays / S. Kulchytsky. - K., 2002. - 950 p. [In Ukrainian]
}

Archives of Public Organizations of Ukraine (hereinafter - (SAPOU), Central State Archives of Supreme Bodies of Power and Government of Ukraine (hereinafter - CSASBPG of Ukraine).

The purpose of the article is to analyze the forms and methods of totalitarian actions of the Party and Soviet bodies on the part of the communist ideology, aimed at repression against the scientific intelligentsia of Ukraine.

Presentation of main material. In any state, under any political regime, the citizen is like a "cog" in the general mechanism, but only a totalitarian, all-encompassing government shamelessly commits executions against those who, in its opinion, poorly perform the functions of such a " $\operatorname{cog}$ ". The slogan of the totalitarian regime could be called "everything for the common good", "common welfare". Here, everything is based on two ideas ideas of social justice and happiness. ${ }^{13}$ In the early 1920s, the authorities purposefully began to repress the intelligentsia. Communist Party leaders assessed the role of the intelligentsia in the life of the new state in terms of a class approach. By social affiliation, the Bolsheviks classified the intelligentsia as an "enemy camp". Thus, a negative attitude was formed towards the intelligentsia as a carrier of "bourgeois" cultural values. Party-Soviet ideology instilled in workers the idea of the existence of two main classes: workers and peasants. The intelligentsia stood out in a separate stratum. The case was not limited to the class approach. The element of destruction was contained in the interpretation of the very concept of "intelligentsia", its place and role in society. The mood of the Party members towards the intelligentsia was not unequivocal. Some of them accepted the idea of cooperation with the old intelligentsia, realizing the importance of its experience and knowledge. Such a view was peculiar only to particular members of the Party. The other part took a "pragmatic approach", given the objective need to cooperate with the old intelligentsia. "Pragmatism" was combined with the desire to subjugate the intelligentsia to the interests of one class - the proletariat, to establish comprehensive control over its activities. This approach was supported by the most influential part of the Party's top leadership. Its supporters were N. Bukharin, V. Lenin, L. Trotsky. Finally, the third group, the most numerous one, treated the intelligentsia either completely negatively or with suspicion and distrust. It

\footnotetext{
${ }^{13}$ Koshovyi, I. Ideological sources of totalitarianism in Plato's philosophy // Herald of Kyiv National University of Trade and Economics. 2020. - №1. - P. 57 [In Ukrainian].
} 
is worth noting that most of their Party members viewed the Ukrainian intelligentsia as a real or potential nationalist force. Such sentiments received the support in the Party apparatus at various levels and had a great influence on the emergence and conduct of repression against the intelligentsia.

Under conditions of authoritarianism and totalitarianism, in the minds of citizens, the subordination of the individual to the social begins to be reflected as something "normal", "normative". Although in totalitarian regimes, there is a negation of individual expressions and individual creative abilities, which are in a rigid coordinate system set by the authorities, beyond which they are severely punished, nevertheless, society and individuals accept such punishments and consider them morally justified. Freudomarxist $\mathrm{E}$. Fromm described this situation in the psychiatric terms of "sadomasochism". ${ }^{14}$ The attitude of the Bolshevik Party and its leaders to the intelligentsia was determined primarily by political and ideological expediency. They deliberately payed no attention to the humanitarian, cultural value of knowledge and activities of the intelligentsia. The founder of the Soviet state V.I. Lenin saw the bourgeois intelligentsia as an adversary, at best, as an inferior social partner which must be strictly controlled by the Party. Lenin did not absolutize this attitude to the intelligentsia. However, it was taken up and inflated to ugliness by its supporters by the force of Bolshevik agitation and propaganda.

The idea of a policy of terror against the intelligentsia in society spread and, as a consequence, found great popular support. In Lenin's mind, this meant, above all, a political solution to the problem of the coexistence of a new society with the intelligentsia. Of course, Lenin understood that the next day after the socialist revolution, scientists, as well as teachers, engineers, and artists would not become communists. In January 1918, at the Third All-Russia Congress of Soviets of Workers', Soldiers' and Peasants' Deputies, he said: "They - professors, teachers, engineers - turn their knowledge into tools of exploitation of workers, saying: I want my knowledge to serve the bourgeoisie, and if not, I will not work". That is, these thoughts of Lenin were instilled in the people, who negatively perceived the intelligentsia and blindly succumbed to ideological propaganda. Lenin wrote: "The working masses, the masses of peasants and workers must overcome the old skills of the intelligentsia and re-educate them-

\footnotetext{
${ }^{14}$ Koshovyi, I. Ideological sources of totalitarianism in Plato's philosophy // Herald of Kyiv National University of Trade and Economics. 2020. - №1. - P. 58 [In Ukrainian].
}

selves to build communism - without this, the construction cannot begin"15.

Lenin paid great attention to the ideological struggle against the intelligentsia. He emphasized: "Our task is to overcome all the resistance of the capitalists, not only military and political, but also ideological, the deepest and most powerful one. The task of our educators is to conduct this mass processing. Its interest, its desire for education and the knowledge of communism that we observe is a guarantee that we will emerge victorious here as well..."16. They tried not only to re-educate the intelligentsia in the communist spirit, but also to use its knowledge. An example is the 1920 directive of the Central Committee of the CPSU to the People's Commissariat for Education, in which Lenin stated: "The success of a communist working in the field (and in institutions) of public education should be measured primarily by how the task of attracting specialists, the ability to find them, the ability to use them, the ability to cooperate with a special educator and a communist leader ... is assigned"17.

The gradual formation of a negative attitude towards the intelligentsia led to the fact that the bureaucracy tried to exploit the broad working class's distrust of scientists. At the Tenth Congress of the Party (1921), anti-specialist sentiments were manifested in speeches by representatives of the "workers' opposition". The following year, 1922, at the Eleventh Congress of the RCP(b), the chairman of the Russian trade unions M.P. Tomsky noted: "If communists speak against specialists at Party meetings and even at non-Party meetings, it means following the path of least resistance. Because the mass, on the grounds of hunger and the desire for equality at all costs, of course, will be incited against the experts. The special lives better, he is paid more, the special commands, demands, the special did not do the October Revolution"18. This attitude towards the intelligentsia found widespread support among the masses.

The Tenth All-Russian Conference of the RCP(b), held on August 4-7, 1922, is a vivid example of how the philosophy of the need to repress the intelligen-

\footnotetext{
${ }^{15}$ Lenin V. Speech at the All-Russian meeting of the Politosvits of the provincial and county departments of public education on November 3, 1920 / V. Lenin // Complete collection of works. - T.41. - K., 1974. - P. 380. [In Ukrainian].

${ }^{16}$ Lenin V. On the work of the Narkompros / V. Lenin // Complete collection of works. - T.41. - K., 1974. - P. 301 [In Ukrainian]. 17 Lenin V. On the work of the Narkompros / V. Lenin // Complete collection of works. - T.41. - K., 1974. - P. 301 [In Ukrainian]. ${ }^{18}$ Kasyanov G. Ukrainian intelligentsia of the 1920s-30s: social portrait and historical destiny / Kasyanov G. - K., 1992. - 25 p. [In Ukrainian].
} 
tsia in peaceful conditions was justified. The main decision made at this conference was as follows: "At the same time, conducting repressions cannot be stopped, not only against the Socialist-Revolutionaries and the Mensheviks, but also against ... the bourgeois-democratic intelligentsia, which for its counter-revolutionary purposes abuses the fundamental interests of entire corporations and for which the real interests of science, technology, pedagogy, cooperation, etc. it is just a dead letter, a political cover". It further stated: "Repressions that inevitably fail to achieve their goal, being directed against the rising class (author's note: as the intelligentsia), are dictated by revolutionary expediency when it comes to suppressing those obsolete groups that try to seize the old positions acquired by the proletariat" ${ }^{\prime 19}$. Thus, repression became a necessary component of the Party's policy during the period of socialist construction.

Lenin's successor J.V. Stalin invented a kind of universal ideological political tool, with which it was possible in those days to justify inhumane actions against individual union republics, their leaders, the intelligentsia, the general population. Accusations of "nationalism" or "nationalist bias" had become such a tool. At the Twelfth Congress of the RCP $(b)$ in 1923, when considering the national question, it was stated: "The bias towards nationalism is harmful because it slows down the process of liberating the national proletariat from the ideological influence of the national bourgeoisie and complicates the process of merging proletarians of different nationalities into a single international organization. Therefore, the fight against nationalist "relics" of the past and, above all, with the chauvinistic forms of these "relics", is one of the tasks of our Party"20. The very fact that the creators turned to topics related to the history of Ukraine was assessed by the Bolsheviks as a manifestation of bourgeois nationalism. The desire to preserve the Ukrainian language was also strongly condemned. Ideological pressure increasingly took the form of ideological terror.

At the Seventh Congress of the RCP(b) in 1930, Stalin informed the Party of the rise of nationalist tendencies as a result of the intensification of the class struggle and the attack of socialism on this front. Therefore, as he emphasized: "Repression in the field of socialist construction is a necessary el-

\footnotetext{
${ }^{19} \mathrm{CPSU}$ in resolutions and decisions of congresses, conferences and plenums of the Central Committee. (1954) - Part 1 M., 1954. - 4.1. - P. 614 p. [In Russian].

${ }^{20} \mathrm{CPSU}$ in resolutions and decisions of congresses, conferences and plenums of the Central Committee. (1954) - Part 1 M., 1954. - 4.1. - 617 p. [In Russian].
}

ement of the offensive, but they are an auxiliary element, not the main one"21. At the same time, these words became a directive for all those involved in the leadership of the state and the Party at various levels. Practice has shown that these people used this "not the main" but "necessary element of the offensive". Repression became the main measure of the totalitarian regime, which was born and established in the USSR.

The struggle of the Communist Party and the Soviet state against the intelligentsia turned into a broad and thoughtful on the so-called "bourgeois ideology" and "petty-bourgeois revolutionism". It was widely implemented in Ukraine as well. A number of decisions were made at conferences of the Central Committee of $\mathrm{CP}(\mathrm{b}) \mathrm{U}$, which agitated the people to fight the so-called "petty-bourgeois" ideology. An example is the Sixth Conference of the $\mathrm{CP}(\mathrm{b}) \mathrm{U}$ in 1921. One of the decisions of the conference stated: "In the struggle against the clerical-nationalist sentiments of the petty-bourgeois environment, which are developing on the basis of new capitalist relations, victory can be achieved only through a real transition to broad intra-Party propaganda and educational work"22. A circular letter from the Central Committee of the $\mathrm{CP}(\mathrm{b}) \mathrm{U}$ to all Gubkoms and Gubpolitprosvits from 1922 stated: “The last Party conference (1921) focused on the struggle against petty-bourgeois ideology. The Party specifically states that a new ideological front is opening before us, and it is quite strong. In the struggle against our opponents we have a rather old and tried weapon: the strengthening of our ideological notions through the propaganda of revolutionary Marxism and the consolidation of our influence in all Soviet cultural organizations that propagate ideology" ${ }^{\prime \prime 2}$. Thus, one of the important forms of struggle against the intelligentsia, with its "bourgeois" ideology, was mass propaganda among society.

Under the leadership of the Central Committee of the Communist Party of Ukraine, in 1925, there was a commission to study the question of the Ukrainian intelligentsia. Its responsibilities included monitoring the political face of the intelligentsia, as well as the work of professors in universities. An example is the work plan of KPI (Kyiv Polytechnic Institute): "Among the professors, the main

\footnotetext{
${ }^{21}$ Kasyanov G. Ukrainian intelligentsia of the 1920s-30s: social portrait and historical destiny / Kasyanov G. - K., 1992. - P. 42. [In Ukrainian].

$22 \mathrm{CPU}$ in resolutions and decisions of congresses and conferences (1918-1956). - K., 1958. - P. 140. [In Ukrainian]. ${ }^{23}$ Central State Archives of Public Organizations of Ukraine. F.1, op.20, d. no. 122. [In Ukrainian].
} 
task in the work is to separate and group its left side, as well as eradicate the most reactionary and monarchical elements of the professorship from the institute" ${ }^{\prime 24}$. That is, the Ukrainian intelligentsia was closely watched and its was actively interfered life. In the 1920s and 1930s, a whole mechanism of such observation was invented - with the help of Agitprovotdel, Glavpolitprosvet and other organizations. Gradually, a whole system of forced "unanimity" was born. Thus, the state supported "ideological discipline", the purpose of which was to destroy any opposition. It is clear that under such conditions, life of the intelligentsia gradually turned into the implementation of directives, resolutions of the Party-Soviet bodies, which were aimed at establishing ideological uniformity in society.

If we talk about the representatives of the Communist Party of Ukraine and their attitude to the intelligentsia, it was rather peculiar. Zatonsky V.P. (member of the Central Committee of (PSU) believed that "the Ukrainian intelligentsia raises its head a little too high", Kahanovich L.M. (member of the Political Bureau of the Central Committee of (PSU) thought that its representatives "become insolent quickly"25. In the preface to the stenographic report on the trial of the Union for the Liberation of Ukraine in 1930, which was directed against the scientific intelligentsia of Ukraine, Secretary of the Central Committee of the $\mathrm{CP}(\mathrm{b})$ Lyubchenko P.P. said the following about the intelligentsia: "The record of the "ULU" process should be a powerful weapon in the hands of the workers to expose the Cain conspiracy carried out by Ukrainian nationalists against the Soviet country. The record of the "ULU" process will tell everyone who the Ukrainian bourgeoisie, the Ukrainian nationalists work for and why, for which "separate" and "independent" Ukraine they are fighting"26. Thus, violence and terror against the intelligentsia were not perceived in working circles as the transformation of the Soviet state into an authoritarian state. With the help of political propaganda, the masses were convinced of the intelligentsia's betrayal of the ideology of communism.

Conclusions. Thus, it is necessary to identify the main features of totalitarianism to find and analyze the ideological sources of this political re-

\footnotetext{
${ }^{24}$ Central State Archives of Public Organizations of Ukraine. F.1, op.20, d. no. 1075 [In Ukrainian].

${ }^{25}$ Podkur R. According to Soviet special services / R. Podkur. K., 2000. - P. 162

${ }^{26}$ Pristaiko V. Victims of terror. How the DPU struggled with Ukrainian academic science. (Political processes of the 20s-30s) / V. Pristaiko // From the archives of the VUCHK, GPU, NKVD, KGB. - №1. - P. 72 [In Ukrainian].
}

gime. It is believed that the main features of the totalitarian regime are most clearly identified by C. Friedrich and Z. Brzezinski ${ }^{27}$. Among them, the following deserve special attention: the implementation of a total ideology, which consists of an official doctrine that covers all important aspects of human life and which is followed by all members of society; the existence of a single mass Party, usually headed by one person ("dictator"); a system of terrorist police control that supports the Party, but also oversees it in the interests of leaders and is characteristically directed not only against "enemies" of the regime, but also against arbitrarily elected classes, and the terror of the secret police systematically uses modern science and especially psychology; technologically conditioned and almost comprehensive control over all mass media the press, radio, cinema, etc. - by the Party and its loyal staff; almost complete Party's control over all armed forces; centralized control and management of the entire economy by means of bureaucratic coordination of its previously "independent" components. Such control, as a rule, extends to all other public organizations and groups.

Giving a general assessment of the terror of the 1920s and 1930s and trying to find some explanation from the point of view of its organizers, it is quite difficult to do so. The destruction of the intellectual power of society is a suicide for society itself. The Party's traditional explanations for this were quite varied. Communist Party leaders tried to explain to the people that the terror was due to intellectual opposition, that is, due to the need to destroy the thinking part of the intelligentsia, which did not accept the idea of Soviet power regarding the proletarian revolution and, in general, the Soviet way of life itself. Another explanation was the struggle against nationalist tendencies, which were equated with counter-revolutionary and terrorist tendencies. The official Stalinist propaganda unequivocally explained the essence of political repression: the victims of the pre-war cleansing were "real enemies". Some researchers, who try to explain the causes of terror, reduce everything to thinking about the mental inferiority of Stalin and his associates. Thus, the philosophical question of the ideological substantiation of the policy of terror by the Party-Soviet leaders towards the intelligentsia of Ukraine remains open and requires further scientific study.

\footnotetext{
27 Friedrich C. Totalitarian dictatorship and autocracy / C.Friedrich, \& Zb. K. Brzezinski. - Cambridge (Mass.): Cambridge (Mass.): Harvard university press, - 1965. - P.22 [in English]
} 


\section{References}

Bilokin S. The mechanism of Bolshevik violence / S. Bilokin. - K., 2000. - 128 p. [In Ukrainian].Central State Archives of Public Organizations of Ukraine. - F.1, op.20, d. no. 1075 [In Ukrainian].

Central State Archives of Public Organizations of Ukraine. - F.1, op.20, d. no. 992. [In Ukrainian].

Chentsov V. Political repression in Soviet Ukraine in the 1920s / V. Chentsov. - Ternopil, 2000. - 482 p. [In Ukrainian].

CPSU in resolutions and decisions of congresses, conferences and plenums of the Central Committee. (1954) - Part 1 M., 1954. - 4.1. - 674 p. [In Russian].

CPU in resolutions and decisions of congresses and conferences (1918 - 1956). - K., 1958. - 140 p. [In Ukrainian].

Danylenko, V. Stalinism in Ukraine: 20-30s / V. Danylenko, G. Kasyanov, S. Kulchytsky. - K., 1991. - 344 p. [In Ukrainian]

Friedrich C. Totalitarian dictatorship and autocracy / C.Friedrich, \& Zb. K. Brzezinski. - Cambridge (Mass.): Cambridge (Mass.): Harvard university press, - 1965. - 254 p. [in English]

Kasyanov G. Ukrainian intelligentsia of the 1920s-30s: social portrait and historical destiny / Kasyanov G. - K., 1992. - 250 p. [In Ukrainian].

Korzhikhina, T. Please be trustworthy / T. Korzhikhina T. - M., 1997.-372 p. [In Russian]

Koshovyi, I. Ideological sources of totalitarianism in Plato's philosophy // Herald of Kyiv National University of Trade and Economics. 2020. - №1. - P. 54 - 69 [In Ukrainian].

Kumanev V. 30s in the destinies of the domestic intelligentsia / Kumanev V. - M.,1991.- 296 p. [In Russian].; Kulchytsky S. Political terror and terrorism in Ukraine in the 19th-20th centuries: historical essays / S. Kulchytsky. - K., 2002. - 950 p. [In Ukrainian].

Lenin V. On the work of the Narkompros / V. Lenin // Complete collection of works. - T.41. - K., 1974. - 313 p. [In Ukrainian].

Lenin V. Speech at the All-Russian meeting of the Politosvits of the provincial and county departments of public education on November 3,1920 / V. Lenin // Complete collection of works. - T.41. - K., 1974. - 383 p. [In Ukrainian].

Ocheretyanko V. Tempered thought / V. Ocheretyanko. - K., 2000. -150 p. [In Ukrainian].;; Podkur R. According to Soviet special services / R. Podkur. - K., 2000. - 230 p. [In Ukrainian].

Popper, K. The Open Society and Its Enemies. Vol. 1: The Spell of Plato; translated from English, ed. by V.N. Sadovsky. - M.: Feniks, 1992. - 448 p. [In Russian].

Pristaiko V. Victims of terror. How the DPU struggled with Ukrainian academic science. (Political processes of the 20s-30s) / V. Pristaiko // From the archives of the VUCHK, GPU, NKVD, KGB. - №1. - P. 70 - 78 [In Ukrainian].

Shapoval Y. In those tragic years: Stalinism in Ukraine / Y. Shapoval. - K., 1990. - 143 p. [In Ukrainian].

Sharapov Yu. From the history of the ideological struggle during the transition to NEP: petty-bourgeois revolutionism - the danger "from the left" / Yu. Sharapov. - M., 1990. -190 p. [In Russian].

Venzher, V. As it was, as it could be, as it became, as it should be / V. Venzher. - M., 1990.-110 p. [In Russian]. 